\title{
Nitrogen fixation in the South Atlantic Gyre and the Benguela Upwelling System
}

\author{
Jill A. Sohm, ${ }^{1}$ Jason A. Hilton, ${ }^{2}$ Abigail E. Noble, ${ }^{3}$ Jonathan P. Zehr, ${ }^{2}$ Mak A. Saito, ${ }^{3}$ \\ and Eric A. Webb ${ }^{1}$ \\ Received 2 June 2011; revised 21 July 2011; accepted 26 July 2011; published 27 August 2011.
}

[1] Dinitrogen $\left(\mathrm{N}_{2}\right)$ fixation is recognized as an important input of new nitrogen $(\mathrm{N})$ to the open ocean gyres, contributing to the export of organic matter from surface waters. However, very little $\mathrm{N}_{2}$-fixation research has focused on the South Atlantic Gyre, where dust deposition of iron (Fe), an important micronutrient for diazotrophs, is seasonally low. Recent modeling efforts suggest that $\mathrm{N}_{2}$-fixation may in fact be closely coupled to, and greatest in, areas of denitrification, as opposed to the oceanic gyres. One of these areas, the Benguela Upwelling System, lies to the east of the South Atlantic Gyre. In this study we show that $\mathrm{N}_{2}$-fixation in surface waters across the South Atlantic Gyre was low overall $\left(<1.5 \mathrm{nmol} \mathrm{N}^{-1} \mathrm{~d}^{-1}\right)$ with highest rates seen in or near the Benguela Upwelling System (up to $\sim 8 \mathrm{nmol} \mathrm{N}^{-1} \mathrm{~d}^{-1}$ ). Surface water dissolved $\mathrm{Fe}$ (dFe) concentrations were very low in the gyre $(\sim 0.3 \mathrm{nM}$ or lower), while soluble reactive phosphorus (SRP) concentrations were relatively high $(\sim 0.15 \mu \mathrm{M})$. $\mathrm{N}_{2}$-fixation rates across the entire sampling area were significantly positively correlated to $\mathrm{dFe}$, but also to SRP and $\mathrm{NO}_{3}^{-}$. Thus, high $\mathrm{NO}_{3}^{-}$concentrations did not exclude $\mathrm{N}_{2}$-fixation in the upwelling region, which provides evidence that $\mathrm{N}_{2}$-fixation may be occurring in previously unrecognized waters, specifically near denitrification zones. However the gene encoding for a nitrogenase component (nifH) was not detected from known diazotrophs at some stations in or near the upwelling where $\mathrm{N}_{2}$-fixation was greatest, suggesting the presence of unknown diazotrophs in these waters. Citation: Sohm, J. A., J. A. Hilton, A. E. Noble, J. P. Zehr, M. A. Saito, and E. A. Webb (2011), Nitrogen fixation in the South Atlantic Gyre and the Benguela Upwelling System, Geophys. Res. Lett., 38, L16608, doi:10.1029/2011GL048315.

\section{Introduction}

[2] Nitrogen $(\mathrm{N})$ is widely recognized as the proximal limiting nutrient in much of the surface ocean [Howarth and Marino, 2006]. $\mathrm{N}_{2}$-fixation provides a source of truly new $\mathrm{N}$ to the photic zone, the magnitude and distribution of which has implications for the functioning of the biologically mediated transfer of carbon to deep waters [Eppley and Peterson, 1979] (biological pump). $\mathrm{N}_{2}$-fixation research has focused on the tropical and subtropical North Atlantic [e.g., Carpenter and Romans, 1991; Capone et al., 2005] and, more recently, the North Pacific [Karl et al., 1997; Dore et al., 2002], while

\footnotetext{
${ }^{1}$ Department of Biological Sciences, University of Southern California, Los Angeles, California, USA.

${ }^{2}$ Department of Ocean Sciences, University of California Santa Cruz, Santa Cruz, California, USA.

${ }^{3}$ Marine Chemistry and Geochemistry Department, Woods Hole Oceanographic Institution, Woods Hole, Massachusetts, USA.
}

Copyright 2011 by the American Geophysical Union. 0094-8276/11/2011GL048315 research in the southern hemisphere gyres is just beginning. $\mathrm{N}_{2}$-fixation might be low in the southern gyres because the delivery of dust rich in $\mathrm{Fe}$ is both modeled and measured to be low compared to their northern counterparts [Han et al., 2008; Mahowald et al., 2005]. Global estimates of $\mathrm{N}_{2}$-fixation based on direct measurements rely heavily on data from the northern hemisphere, but our ability to predict the importance of $\mathrm{N}_{2}-$ fixation on the carbon cycle depends upon understanding the true global distribution of this process.

[3] Recently, a model study of nutrient ratios in surface waters suggested that the greatest amounts of $\mathrm{N}_{2}$-fixation are not occurring in the inorganic $\mathrm{N}$ poor waters of the gyres, where research has been focused, but rather is closely coupled to areas of denitrification through the upwelling of waters that are depleted in N relative to phosphorus (P) [Deutsch et al., 2007]. However, much of these waters contain significant amounts of $\mathrm{N}$, making it hard to reconcile with the current view of the ideal environmental conditions for oceanic $\mathrm{N}_{2}$-fixation. Some analyses of the global $\mathrm{N}$ budget currently show an imbalance, with sinks (denitrification and anammox) far outweighing sources $\left(\mathrm{N}_{2}\right.$-fixation) [Codispoti, 2007]. If this is indeed correct, undiscovered $\mathrm{N}_{2}$-fixation near upwelling regions could be important for bringing the $\mathrm{N}$ budget into balance. The Benguela Upwelling System, the most productive upwelling zone in the world [Carr, 2001], is one of the areas where Deutsch et al. [2007] predict high $\mathrm{N}_{2}$ fixation rates, and thus provides an opportunity to test their hypothesis.

[4] $\mathrm{N}_{2}$-fixation in the open ocean is carried out by a small number of groups of prokaryotes. Trichodesmium, a nonheterocystous filamentous cyanobacterium has been the most well studied, but unicellular diazotrophs are also quantitatively important and contribute significantly to $\mathrm{N}_{2}$-fixation [Montoya et al., 2004]. This group includes UCYN-A, a putative cyanobacterium lacking photosystem II [Tripp et al., 2010]; group $\mathrm{B}$, or Crocosphaera watsonii; and the unidentified UCYN-C [Foster et al., 2007]. In specific locations, heterotrophic bacteria or diazotrophic symbionts of diatoms (Richelia) may also be important [e.g., Foster et al., 2007, 2009]. To assess diazotrophic abundance and activity in the South Atlantic in austral spring 2007, we measured the rate of $\mathrm{N}_{2}$-fixation using ${ }^{15} \mathrm{~N}_{2}$ uptake across the gyre and into the Benguela Upwelling System, used a quantitative PCR method (qPCR) to detect unicellular cyanobacterial groups UCYN-A and Crocosphaera, and looked for Trichodesmium and Richelia with net tows and microscopy.

\section{Methods}

\subsection{Sample Collection}

[5] Samples were collected in the South Atlantic on a cruise on the R/V Knorr in November and December of 
2007, timed to occur during a period of simultaneous upwelling and low dust input. Temperature and salinity data were collected with a CTD sensor attached to a sampling rosette. Surface water samples for both $\mathrm{N}_{2}$-fixation and nifH gene copy analysis were collected off a surface pump deployed at $8 \mathrm{~m}$, while depth profile samples for $\mathrm{N}_{2}$-fixation and nifH gene copy were sampled off a CTD rosette at depths of 20, 40, 70, and $110 \mathrm{~m}$. Incubation bottles were acid washed and rinsed with milli-Q water before each incubation. Samples for nutrient analysis were collected from a trace metal clean rosette sampler at a depth of $10 \mathrm{~m}$.

\section{2. $\mathrm{N}_{2}$-Fixation Measurements}

[6] $\mathrm{N}_{2}$-fixation was measured with a stable isotope enrichment method in whole water samples. $4.5 \mathrm{~L}$ polycarbonate bottles were filled with sample water, air bubbles were removed, bottles were tightly capped with a septa cap and $3 \mathrm{ml}$ of ${ }^{15} \mathrm{~N}_{2}$ gas added. After a 24 hour incubation in a deckboard incubator flushed with flowing seawater, samples were filtered onto pre-combusted GF/F and frozen for later analysis. The $8 \mathrm{~m}$ samples were incubated at $40 \%$ incident light and the 20-70 m samples were incubated at $30 \%$ incident light. Because of the potential light dependence of $\mathrm{N}_{2}$-fixation and the attenuation of light through the water column, integrated rates may be overestimated slightly at stations in the gyre, however, in the upwelling, the very strong attenuation of light could have led to $\mathrm{N}_{2}$-fixation rate underestimation.

[7] In the lab, samples were dried and pelletized in aluminum foil, then analyzed for $\mathrm{N}$ content and stable isotope mass ratio $\left(\delta^{15} \mathrm{~N}\right)$ at the UC Davis Stable Isotope Facility. $\delta^{15} \mathrm{~N}$ values were corrected using internal standards, and the limit of detection (below which $\delta^{15} \mathrm{~N}$ values were unreliable) was $1 \mu \mathrm{mol} \mathrm{N}$. $\mathrm{N}_{2}$-fixation rates were calculated as described previously [Montoya et al., 1996]. At stations where biomass was high enough, some samples were filtered through a $10 \mu \mathrm{m}$ polycarbonate filter then caught on a $\mathrm{GF} / \mathrm{F}$ after incubation, to see if $\mathrm{N}_{2}$-fixation could be attributed to the $<10 \mu \mathrm{m}$ fraction.

\subsection{The nifH Copy Number}

[8] Raw seawater (2 L) for DNA samples were filtered through $10 \mu \mathrm{m}$, polyester filters (Osmonics, Inc.) in-line with $0.2 \mu \mathrm{m}$ Supor filters (Pall Corporation) held in Swinnex filter holders $(25 \mathrm{~mm}$ in diameter, Millipore) using a peristaltic pump. Filters were then placed in $2 \mathrm{~mL}$ bead-beater tubes (Sarstedt) with a mixture of $0.1 \mathrm{~mm}$ and $0.5 \mathrm{~mm}$ glass beads (BioSpec Products), kept in liquid nitrogen while at sea, and stored at $-80^{\circ} \mathrm{C}$ in the lab until extracted.

[9] DNA was extracted following the Qiagen DNeasy Plant Mini Kit protocol with minor modifications. The protocol supplied by the manufacturer was followed with the addition of a 2 minute bead-beating step, followed by the addition of $45 \mu \mathrm{L}$ Proteinase-K solution (Qiagen), and a $1 \mathrm{hr}$ incubation at $55^{\circ} \mathrm{C}$ with moderate shaking.

[10] nifH gene abundance was estimated for Group A and Group B unicellular diazotrophs, the het-1, het-2 and het-3 heterocystous groups and a gamma proteobacteria by quantitative polymerase chain reaction (qPCR) using previously designed primer-probe sets [Church et al., 2005]. Run in triplicate, $2 \mu \mathrm{L}$ of extracted DNA was added to $23 \mu \mathrm{L}$ qPCR reaction mixture containing $1 \mu \mathrm{L}$ of each primer, $0.5 \mu \mathrm{L}$ of probe, and 2x Master Mix (Applied Biosystems). The thermal cycling used for amplification began with a 2 minute step at $50^{\circ} \mathrm{C}$ and a 10 minute step at $95^{\circ} \mathrm{C}$, followed by 45 cycles consisting of 15 seconds at $95^{\circ} \mathrm{C}$ and 1 minute at $60^{\circ} \mathrm{C}$. Amplifications were done on the Applied Biosystems 7500 Real Time PCR machine using the 7500 System SDS software. A standard curve was created by using a series of eight 10-fold diluted standards, in duplicate. At least three No Template Controls were used as negative controls for each qPCR plate.

\subsection{The dFe and Nutrient Concentrations}

[11] Dissolved metal samples were collected by clean rosette and $8 \mathrm{~L} \mathrm{X-Niskin} \mathrm{sampler} \mathrm{bottles} \mathrm{on} \mathrm{a} \mathrm{non-metallic} \mathrm{wire.}$ Seawater was filtered through $0.4 \mu \mathrm{m}$ polycarbonate filters in a clean environment into low-density polyethylene bottles and acidified to $\mathrm{pH} 1.7$ using $\mathrm{HCl}$ (Seastar). Total dissolved iron was measured by inductively coupled plasma mass spectrometry (Thermo Element 2) as previously described [Saito and Schneider, 2006]. Briefly, $13 \mathrm{~mL}$ aliquots of acidified seawater were weighed into acid-leached polypropylene centrifuge tubes, spiked with ${ }^{57} \mathrm{Fe}$ for isotope dilution analysis and allowed to equilibrate overnight. Concentrated ammonium hydroxide (Seastar) was added to induce $\mathrm{Mg}(\mathrm{OH})_{2}$ and trace metal co-precipitation for 3 minutes, followed by centrifugation for 3 minutes at $3000 \mathrm{rpm}(1460 \times \mathrm{g})$. The sample was decanted, centrifuged and decanted again, and the pellet was re-dissolved in 5\% nitric acid (Seastar) with $1 \mathrm{ppb}$ indium. The $5 \%$ nitric acid resuspension solution was used to determine the iron blank, and signal suppression due to matrix effects was accounted for using a ratio of the indium in the blank and sample. SAFe seawater intercalibration standards were analyzed at the beginning of each analysis day with iron concentrations of $0.96 \pm 0.095 \mathrm{nM}$ for D2 and $0.125 \pm 0.046$ for $\mathrm{S} 1(\mathrm{n}=10)$, which are within the reported ranges of $0.91+0.17 \mathrm{nM}$ and $0.097+0.043 \mathrm{nM}$ [Johnson et al., 2007]. $\mathrm{SRP}$ and $\mathrm{NO}_{3}^{-}$concentrations were determined using a continuous flow nutrient autoanalyzer and standard colorimetric methods (http://chemoc.coas.oregonstate.edu/ /gordon/).

\section{Results and Discussion}

[12] Surface temperatures were near $26^{\circ} \mathrm{C}$ in the western South Atlantic gyre and decreased across the basin to as cold as $16^{\circ} \mathrm{C}$ in the upwelling region (Figure 1a). The relatively high temperatures at stations 17,18 and 19, indicate that these waters are part of the Angola-Benguela Frontal Zone, or ABFZ, that occurs around $15^{\circ} \mathrm{S}$ [Kostianoy and Lutjeharms, 1999]. Temperatures below $25^{\circ} \mathrm{C}$ are known to substantially reduce the growth rate of Trichodesmium [Breitbarth et al., 2007], so it is not surprising that it was not seen in net tows throughout the entire cruise track. Nitrate $\left(\mathrm{NO}_{3}^{-}\right)$concentrations in surface waters ranged from below detection to $\sim 0.2 \mu \mathrm{M}$ in the gyre, but were much higher, $\sim 5-27 \mu \mathrm{M}$, in the ABFZ and Benguela Upwelling System. Surface soluble reactive phosphorus (SRP) concentrations were high in the gyre, $\sim 0.15-0.25 \mu \mathrm{M}$, compared to the North Atlantic, where surface values are generally below $0.05 \mu \mathrm{M}$ [Sohm and Capone, 2010]. The total dissolved iron $(\mathrm{dFe})$ concentrations in surface waters $(10 \mathrm{~m})$ were also low in the gyre, ranging from $0.08-0.34 \mathrm{nM}$, and much higher at the upwelling stations, up to $2.4 \mathrm{nM}$.

[13] $\mathrm{N}_{2}$-fixation was detected in whole water surface samples ( $8 \mathrm{~m}$ depth) at many stations, but at generally low rates (Figure 2). $\mathrm{N}_{2}$-fixation was very low $\left(<0.6 \mathrm{nmol} \mathrm{N}{ }^{-1} \mathrm{~d}^{-1}\right)$ or below detection in the central gyre while in the eastern gyre, 


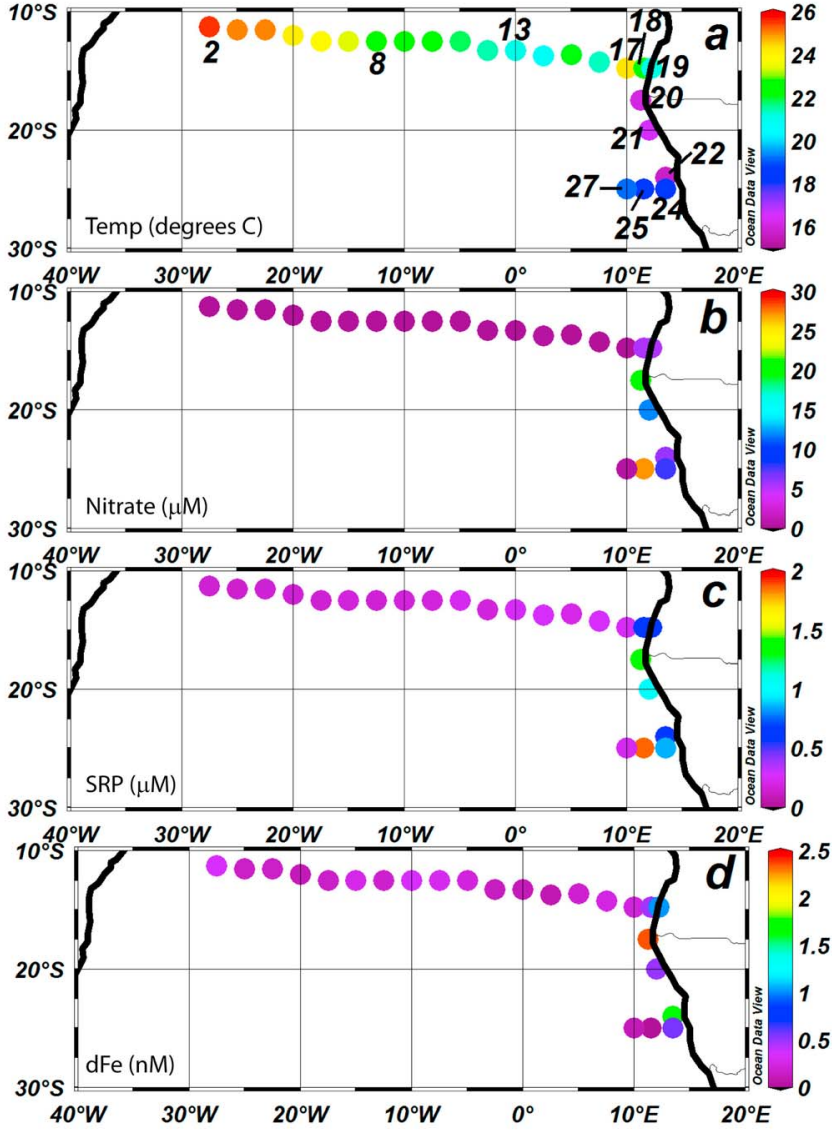

Figure 1. Hydrographic, macro-, and micro-nutrient characteristics of water at $10 \mathrm{~m}$ in the South Atlantic in November/December 2007: (a) temperature $\left({ }^{\circ} \mathrm{C}\right)$, (b) nitrate $(\mu \mathrm{M})$, (c) soluble reactive phosphorus $(\mu \mathrm{M})$, and (d) total dissolved Fe (nM). The effect of the Benguela Upwelling System on all parameters can be clearly seen.
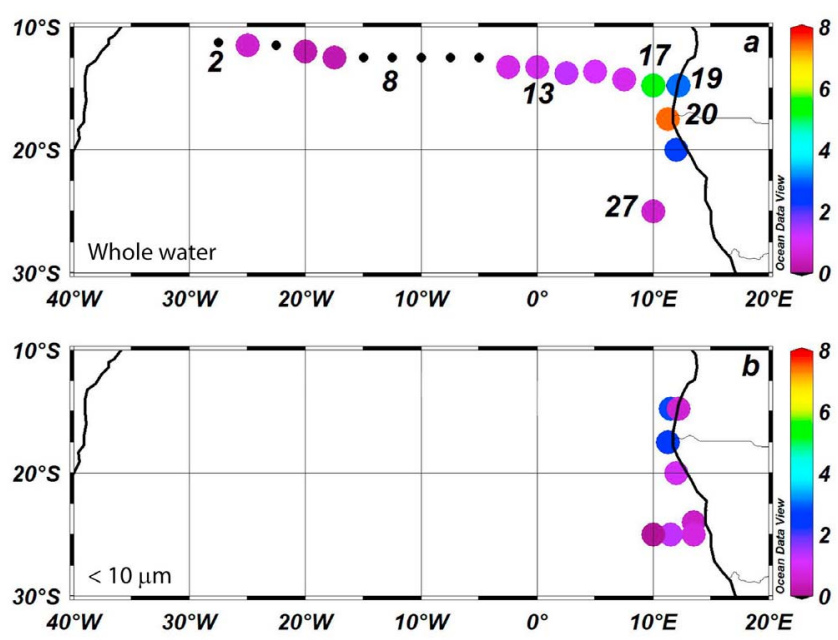

Figure 2. $\mathrm{N}_{2}$-fixation ( $\mathrm{nmol} \mathrm{l}^{-1} \mathrm{~d}^{-1}$ ) in samples from $8 \mathrm{~m}$ in (a) whole water samples and (b) the $<10 \mu \mathrm{m}$ fraction. Black dots indicate stations where $\mathrm{N}_{2}$ fixation was assayed but activity was below detection.
Table 1. Integrated $\mathrm{N}_{2}$-Fixation Rates From the Surface to $70 \mathrm{~m}$ at Three Locations in the South Atlantic During November/December 2007

\begin{tabular}{ccccc}
\hline Station & Date & Latitude $\left({ }^{\circ} \mathrm{N}\right)$ & Longitude $\left({ }^{\circ} \mathrm{E}\right)$ & Areal $\mathrm{N}_{2}$ Fixation Rate \\
\hline & & & & $\left(\mu \mathrm{mol} \mathrm{N} \mathrm{m}^{-2} \mathrm{~d}^{-1}\right)$ \\
3 & $20 \mathrm{Nov} 07$ & -11.5 & 335 & 25 \\
13 & $01 \operatorname{Dec} 07$ & -13.25 & 0 & 22 \\
19 & $05 \operatorname{Dec} 07$ & -14.75 & 12.2 & 85 \\
\hline
\end{tabular}

from $2.5^{\circ} \mathrm{W}$ to $7.5^{\circ} \mathrm{E}$, rates were somewhat higher at $\sim 1 \mathrm{nmol}$ $\mathrm{N}^{-1} \mathrm{~d}^{-1}$. The highest rates seen on this cruise were in the ABFZ and the Benguela Upwelling System $\left(\sim 2-8 \mathrm{nmol} \mathrm{N}^{-1}\right.$ $\mathrm{d}^{-1}$; stations 17-20). Depth integrated $\mathrm{N}_{2}$-fixation in whole water samples (to $70 \mathrm{~m}$ ) was $\sim 25 \mu \mathrm{mol} \mathrm{N} \mathrm{m}{ }^{-2} \mathrm{~d}^{-1}$ at gyre stations 3 and 13, and three times as high, $85 \mu \mathrm{mol} \mathrm{N} \mathrm{m}{ }^{-2} \mathrm{~d}^{-1}$, at station 19 (Table 1). Staal et al. [2007] investigated $\mathrm{N}_{2}$ fixation activity at the same latitudes as this study using an on-line acetylene reduction technique and found no activity, although their research was carried out in January and February when upwelling intensity seemed to be low (based on temperature). Size fractionation showed that $\mathrm{N}_{2}$-fixation was occurring in both the $>10 \mu \mathrm{m}$ and the $<10 \mu \mathrm{m}$ fraction at stations 17-25. The small size fraction accounted for only $20-35 \%$ of the total activity at stations $19-21$ (Figure 2 ). This may be accounted for by the aggregation of small cells, attachment of small diazotrophs to particles, or the possibility that UCYN-A is a symbiont or lives in association with a larger organism [Tripp et al., 2010].

[14] Crocosphaera and UCYN-A were detected but not quantifiable at many stations. UCYN-A was also found at very high abundances in the ABFZ stations 17 and 19 (Figure 3, Table $\mathrm{S} 1$ of the auxiliary material). ${ }^{1}$ Richelia was not observed microscopically.

[15] Low temperature waters have not traditionally been seen as areas of $\mathrm{N}_{2}$-fixation, however recent studies are beginning to show the occurrence of activity in colder waters. Holl et al. [2007] found rates off the west coast of Australia at temperatures of $15-18{ }^{\circ} \mathrm{C}$ comparable to our study in the South Atlantic Gyre, Needoba et al. [2007] measured similar rates in waters $<19^{\circ} \mathrm{C}$ off the coast of California, and Rees et al. [2009] found rates of an order of magnitude higher in the English Channel at temperatures of $18-20^{\circ} \mathrm{C}$. However, $\mathrm{NO}_{3}^{-}$concentrations were low in all three studies [Holl et al., 2007; Needoba et al., 2007; Rees et al., 2009].

[16] Waters with $\mathrm{NO}_{3}^{-}$concentrations near the detection limit and relatively high SRP are typically considered ideal for $\mathrm{N}_{2}$-fixation, however, this was not the case at the time of this cruise. Rather, $\mathrm{N}_{2}$-fixation in whole water samples was undetectable or extremely low in the South Atlantic gyre. Moore et al. [2009] also found little to no $\mathrm{N}_{2}$-fixation on a meridional transect through the South Atlantic, and hypothesized that the very low $\mathrm{dFe}$ concentrations there prevented substantial activity. dFe concentrations measured in surface waters $(10 \mathrm{~m})$ on this zonal transect through the gyre were $\leq 0.34 \mathrm{nM}$, possibly low enough to prevent the growth of diazotrophic organisms. In fact, whole water $\mathrm{N}_{2}$-fixation rates for the entire cruise were highly positively correlated to surface $\mathrm{dFe}$ concentrations $\left(\mathrm{r}^{2}=0.82, \mathrm{p}<0.001\right)$. However, $\mathrm{N}_{2}$-fixation was also significantly correlated to $\mathrm{NO}_{3}^{-}$and

${ }^{1}$ Auxiliary materials are available in the HTML. doi:10.1029/ 2011 GL048315. 


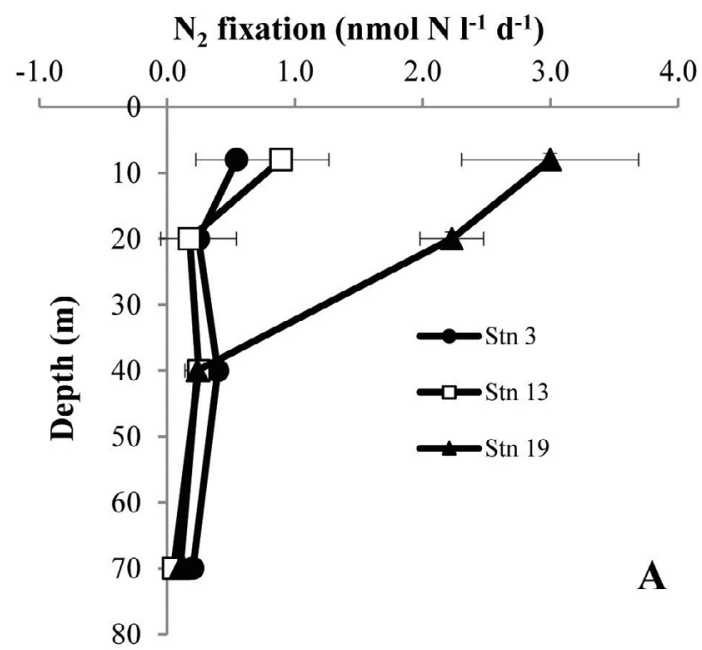

Log nifH copies $\mathrm{L}^{-1}$

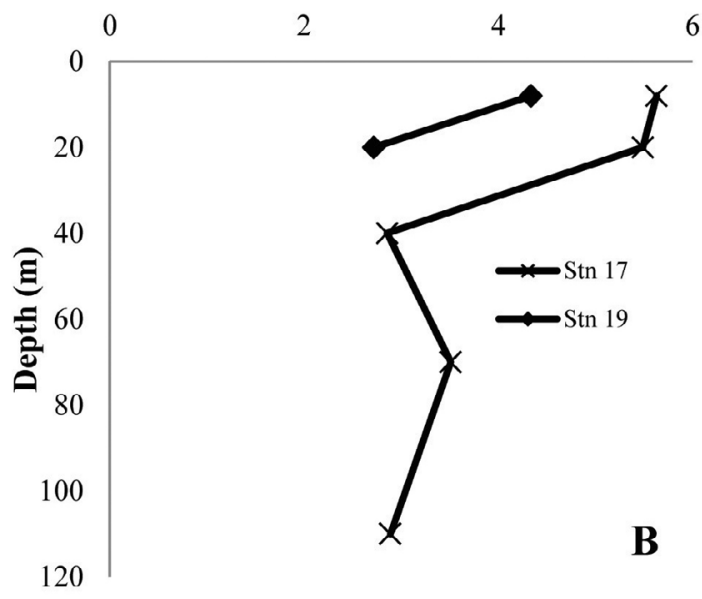

Figure 3. (a) Depth profiles of whole water $\mathrm{N}_{2}$-fixation at three stations along the cruise track and (b) the abundance of nifH gene copies of UCYN-A at two stations in the AngolaBenguela Frontal Zone.

SRP concentrations $\left(\mathrm{r}^{2}=0.78, \mathrm{p}<0.002\right.$ for both correlations). This arises from the fact that $\mathrm{dFe}, \mathrm{NO}_{3}^{-}$and SRP were significantly correlated to each other in surface waters $\left(\mathrm{r}^{2}>\right.$ $0.89, \mathrm{p}<0.001)$ and suggests that the major source of $\mathrm{dFe}$ to surface waters in this region at the time of this study was not atmospheric dust inputs (in fact the cruise was designed to occur in a low dust flux period). Rather, observations of large plumes of iron and cobalt emanating from the ABFZ region at intermediate depths during this cruise suggest the source of $\mathrm{Fe}$ is the resuspension and dissolution of metals from shelf sediments in contact with low oxygen waters (Noble, A.E., M.A. Saito, C.H. Lamborg, D.C. Ohnemus, P. J. Lam, T.J. Goepfert, C.H. Frame, K.L. Casciotti, and J. Jennings, Basin-scale inputs of cobalt, iron, and manganese from the Benguela-Angola front into the South Atlantic Ocean, submitted to Limnology and Oceanography, 2011). In addition, much of the South Atlantic gyre region is predicted to have low atmospheric iron inputs, particularly in relation to the large inputs from the Saharan desert that occur in the North Atlantic [Mahowald et al., 2005].
[17] While dFe and SRP concentrations were likely high enough in the ABFZ and Benguela Upwelling System to support $\mathrm{N}_{2}$-fixation, interestingly, $\mathrm{NO}_{3}^{-}$concentrations in the micromolar range did not inhibit $\mathrm{N}_{2}$-fixation. In fact, the highest rate measured in whole water samples $\left(7.5 \mathrm{nmol}^{-1}\right.$ $\left.\mathrm{d}^{-1}\right)$ was found at the station with very high $\mathrm{NO}_{3}^{-}(21 \mu \mathrm{M})$. Additionally, UCYN-A was highly abundant in waters with $\sim 5 \mu \mathrm{M} \mathrm{NO}_{3}^{-}$, but shows no evidence of having $\mathrm{NO}_{3}^{-}$transporters or $\mathrm{NO}_{3}^{-}$reductase in its genome (Tripp et al. [2010] did not report a $\mathrm{NO}_{3}^{-}$transporter in their analysis of transporters present, and the absence of any known $\mathrm{NO}_{3}^{-}$transporter was confirmed by Rapid Annotation using Subsystem Technology (RAST) comparison of Cyanothece str. 51142 transporters to UCYN-A (H.J. Tripp, unpublished data, 2011)). These discoveries show that high $\mathrm{NO}_{3}^{-}$concentrations do not necessarily preclude the presence of diazotrophs or $\mathrm{N}_{2}$-fixation, although $\mathrm{N}_{2}$-fixation could be somewhat reduced at these concentrations compared to what it would be if the water were devoid of $\mathrm{NO}_{3}^{-}$, and that $\mathrm{N}_{2}$-fixation can occur near areas known to support denitrification, as predicted by Deutsch et al. [2007]. It is difficult to reconcile these results with conventional wisdom regarding the environmental conditions that promote $\mathrm{N}_{2}$-fixation, and it suggests a poor understanding of the environmental conditions experienced by diazotrophs on the cellular scale: perhaps there are unrecognized microzones of low fixed $\mathrm{N}$ related to particles that promote $\mathrm{N}_{2}$-fixation, the timescales of exposure to fixed $\mathrm{N}$ are incongruent with the timescale of regulation of $\mathrm{N}_{2}$-fixation, or oceanic $\mathrm{N}_{2}$-fixation may not be regulated at environmentally relevant concentrations of fixed $\mathrm{N}$ in all oceanic diazotrophs.

[18] The whole water $\mathrm{N}_{2}$-fixation rates measured in the ABFZ and northern Benguela Upwelling System are comparable to surface rates seen in areas classically considered important locations of $\mathrm{N}_{2}$-fixation: the oligotrophic areas of the North Atlantic $\left(\sim 200 \mu \mathrm{mol} \mathrm{N} \mathrm{m}{ }^{-2} \mathrm{~d}^{-1}\right)$ and North Pacific ( 20-110 $\mu \mathrm{mol} \mathrm{N} \mathrm{m}{ }^{-2} \mathrm{~d}^{-1}$ over an annual cycle) [Moore et al., 2009; Grabowski et al., 2008]. The depth integrated rate at station $19\left(85 \mu \mathrm{mol} \mathrm{N} \mathrm{m}{ }^{-2} \mathrm{~d}^{-1}\right)$ was also comparable to these locations, while the rates calculated in the gyre, although low by comparison, were measurable. $\mathrm{N}_{2}$-fixation has also been seen at one station in the upwelling region off central Chile [Raimbault and Garcia, 2008], but our study shows that $\mathrm{N}_{2}$-fixation can be widespread in an upwelling region with high $\mathrm{NO}_{3}^{-}$concentrations, sometimes at high rates, and in both the $<10$ and $>10 \mu \mathrm{m}$ fractions. It is important to note, however, that Staal et al. [2007] did not detect $\mathrm{N}_{2}$ fixation in an area near our study, but at a time when upwelling did not appear to be strong.

[19] The organisms likely responsible for this activity could only be identified at stations 17 and 19. UCYN-A cyanobacteria were present at these stations in high abundance. At all other stations, $\mathrm{N}_{2}$-fixation could not be specifically attributed to UCYN-A or Crocosphaera, based on qPCR analysis of DNA. Furthermore, Trichodesmium was never seen in net tows, nor were heterocystous diatom symbionts seen in microscope slide samples. Station 20 samples, where surface $\mathrm{N}_{2}$-fixation rates were highest, were also tested for the presence of a third unicellular cyanobacteria (UCYN-C), three heterocystous symbiotic species (het-1, het-2, het-3) and one group of gamma proteobacteria using qPCR; all were not detected in the $0.2-10 \mu \mathrm{m}$ fraction while het- 1 and het- 2 were detected but not quantifiable in the $>10 \mu \mathrm{m}$ fraction. 
Undetectable or unquantifiable densities of cyanobacterial diazotrophs may be able to carry out $\mathrm{N}_{2}$-fixation at measurable rates. Alternatively, we suggest that heterotrophic bacteria could also be responsible for the activity in the upwelling regions, in both free-living and particle associated forms, as evidenced by the presence of activity in whole water samples and, at lower rates, in the $<10 \mu \mathrm{m}$ fraction. In fact, Langlois et al. [2008] did find gamma-proteobacteria to be widespread in the North Atlantic. If the organisms fixing $\mathrm{N}$ in the Benguela Upwelling System are heterotrophic, it is unclear how they would deal with potential oxygen poisoning or what the source of organic carbon is, although particle association could be one solution.

[20] To estimate the contribution of the Benguela Upwelling System to marine $\mathrm{N}_{2}$-fixation, the depth profile from station 19 was used as a model of the percent decrease in activity with depth. This model was applied to stations in the upwelling region where $\mathrm{N}_{2}$-fixation was measured, the surface value being used to estimate $\mathrm{N}_{2}$-fixation at different depths and then water column integrated values. These values were averaged for each of three geographic ranges of the Benguela described by Carr [2001], 500 miles offshore at $15-19,19-24$ and $24-29^{\circ} \mathrm{S}$, and multiplied by the surface area of those geographic ranges. Adding these values together and assuming an upwelling period of 100 days gives a final estimate of $5.5 \times 10^{9} \mathrm{~mol} \mathrm{~N} \mathrm{y}^{-1}$ (or $0.077 \mathrm{Tg} \mathrm{N}$ $\left.\mathrm{y}^{-1}\right)$. It is important to note that the depth profile from station 19 is not necessarily representative of other stations in the upwelling region, however, this is a first approximation and is likely within the range of the true value.

[21] These data show that the South Atlantic Gyre has low potential for supporting $\mathrm{N}_{2}$-fixation and serve to extend the range of $\mathrm{N}_{2}$-fixation into the Benguela Upwelling System, specifically, and potentially into cold, nutrient-rich waters in general. Some estimates of the marine $\mathrm{N}$ cycle suggest that inputs and outputs are currently unbalanced [Codispoti, 2007], with outputs (denitrification and anammox) far outweighing inputs ( $\mathrm{N}_{2}$-fixation). If $\mathrm{N}_{2}$-fixation is found to be widespread in upwelling regions, this could help to reconcile the nitrogen budget imbalance. Furthermore, our data imply that unidentified diazotrophs may be fixing $\mathrm{N}_{2}$ in upwelling regions. Heterotrophic bacteria are one possibility; however, careful experiments in future studies are needed to substantiate this hypothesis and determine the organisms responsible and the adaptations that they possess.

[22] Acknowledgments. The authors would like to thank the captain and crew of the R/V Knorr for assistance out at sea, Joe Jennings for nutrient analyses, and Scot Birdwhistell for assistance in the WHOI ICP-MS facility. Funding for this research was provided by NSF grants OCE-0452883 (to E.A.W. and M.A.S.), OCE-0825922 (to E.A.W.), and The Gordon and Betty Moore Foundation (JPZ).

[23] The Editor thanks Lucas Stal and an anonymous reviewer for their assistance in evaluating this paper.

\section{References}

Breitbarth, E., A. Oschlies, and J. LaRoche (2007), Physiological constraints on the global distribution of Trichodesmium-Effect of temperature on diazotrophy, Biogeosciences, 4, 53-61, doi:10.5194/bg-4-53-2007.

Capone, D. G., J. A. Burns, J. P. Montoya, A. Subramaniam, C. Mahaffey, T. Gunderson, A. F. Michaels, and E. J. Carpenter (2005), Nitrogen fixation by Trichodesmium spp.: An important source of new nitrogen to the tropical and subtropical North Atlantic Ocean, Global Biogeochem. Cycles, 19, GB2024, doi:10.1029/2004GB002331.
Carpenter, E. J., and K. Romans (1991), Major role of the Cyanobacterium Trichodesmium in nutrient cycling in the North-Atlantic Ocean, Science, 254, 1356-1358, doi:10.1126/science.254.5036.1356.

Carr, M. E. (2001), Estimation of potential productivity in Eastern Boundary Currents using remote sensing, Deep Sea Res., Part I, 49, 59-80, doi:10.1016/S0967-0645(01)00094-7.

Church, M. J., B. D. Jenkins, D. M. Karl, and J. P. Zehr (2005), Vertical distributions of nitrogen-fixing phylotypes at Stn ALOHA in the oligotrophic North Pacific Ocean, Aquat. Microb. Ecol., 38, 3-14, doi:10.3354/ ame 038003 .

Codispoti, L. A. (2007), An oceanic fixed nitrogen sink exceeding $400 \mathrm{Tg}$ $\mathrm{N} \mathrm{a}^{-1}$ vs the concept of homeostasis in the fixed-nitrogen inventory, Biogeosciences, 4, 233-253, doi:10.5194/bg-4-233-2007.

Deutsch, C., J. L. Sarmiento, D. M. Sigman, N. Gruberand, and J. P. Dunne (2007), Spatial coupling of nitrogen inputs and losses in the ocean, Nature, 445, 163-167, doi:10.1038/nature05392.

Dore, J. E., J. R. Brum, L. M. Tupas, and D. M. Karl (2002), Seasonal and interannual variability in sources of nitrogen supporting export in the oligotrophic subtropical North Pacific Ocean, Limnol. Oceanogr., 47, 1595-1607, doi:10.4319/lo.2002.47.6.1595.

Eppley, R. W., and B. J. Peterson (1979), Particulate organic-matter flux and planktonic new production in the deep ocean, Nature, 282, 677-680, doi: $10.1038 / 282677 \mathrm{a} 0$.

Foster, R. A., A. Subramaniam, C. Mahaffey, E. J. Carpenter, D. G. Capone, and J. P. Zehr (2007), Influence of the Amazon River plume on distributions of free-living and symbiotic cyanobacteria in the western tropical north Atlantic Ocean, Limnol. Oceanogr., 52, 517-532, doi:10.4319/ lo.2007.52.2.0517.

Foster, R. A., A. Paytan, and J. P. Zehr (2009), Seasonality of $\mathrm{N}_{2}$ fixation and nifH gene diversity in the Gulf of Aqaba (Red Sea), Limnol. Oceanogr., 54, 219-233, doi:10.4319/lo.2009.54.1.0219.

Grabowski, M. N. W., M. J. Church, and D. M. Karl (2008), Nitrogen fixation rates and controls at Stn ALOHA, Aquat. Microb. Ecol., 52, 175-183, doi:10.3354/ame01209.

Han, Q., J. K. Moore, C. Zender, C. Measures, and D. Hydes (2008), Constraining oceanic dust deposition using surface ocean dissolved $\mathrm{Al}$, Global Biogeochem. Cycles, 22, GB2003, doi:10.1029/2007GB002975.

Holl, C. M., A. M. Waite, S. Pesant, P. A. Thompson, and J. P. Montoya (2007), Unicellular diazotrophy as a source of nitrogen to Leeuwin Current coastal eddies, Deep Sea Res., Part II, 54, 1045-1054, doi:10.1016/j. dsr2.2007.02.002

Howarth, R. W., and R. Marino (2006), Nitrogen as the limiting nutrient for eutrophication in coastal marine ecosystems: Evolving views over three decades, Limnol. Oceanogr., 51, 364-376, doi:10.4319/lo.2006.51.1 part_2.0364.

Johnson, K. S., et al. (2007), The SAFe iron intercomparison cruise: An international collaboration to develop dissolved iron in seawater standards, Eos Trans. AGU, 88, 131-132, doi:10.1029/2007EO110003.

Karl, D., R. Letelier, L. Tupas, J. Dore, J. Christian, and D. Hebel (1997), The role of nitrogen fixation in biogeochemical cycling in the subtropical North Pacific Ocean, Nature, 388, 533-538, doi:10.1038/41474.

Kostianoy, A. G., and J. R. E. Lutjeharms (1999), Atmospheric effects in the Angola-Benguela frontal zone, J. Geophys. Res., 104, 20,963-20,970, doi:10.1029/1999JC900017.

Langlois, R. J., D. Hummer, and J. LaRoche (2008), Abundances and distributions of the dominant nifH phylotypes in the Northern Atlantic Ocean, Appl. Environ. Microbiol., 74, 1922-1931, doi:10.1128/AEM.01720-07.

Mahowald, N. M., A. R. Baker, G. Bergametti, N. Brooks, R. A. Duce, T. D. Jickells, N. Kubilay, J. M. Prospero, and I. Tegen (2005), Atmospheric global dust cycle and iron inputs to the ocean, Global Biogeochem. Cycles, 19, GB4025, doi:10.1029/2004GB002402.

Montoya, J. P., M. Voss, P. Kahler, and D. G. Capone (1996), A simple, high-precision, high-sensitivity tracer assay for $\mathrm{N}_{2}$ fixation, Appl. Environ. Microbiol., 62, 986-993.

Montoya, J. P., C. M. Holl, J. P. Zehr, A. Hansen, T. A. Villareal, and D. G. Capone (2004), High rates of $\mathrm{N}_{2}$ fixation by unicellular diazotrophs in the oligotrophic Pacific Ocean, Nature, 430, 1027-1032, doi:10.1038/ nature 02824 .

Moore, C. M., et al. (2009), Large-scale distribution of Atlantic nitrogen fixation controlled by iron availability, Nat. Geosci., 2, 867-871, doi:10.1038/ ngeo667.

Needoba, J. A., R. A. Foster, C. Sakamoto, J. P. Zehr, and K. S. Johnson (2007), Nitrogen fixation by unicellular diazotrophic cyanobacteria in the temperate oligotrophic North Pacific Ocean, Limnol. Oceanogr., 52, 1317-1327, doi:10.4319/lo.2007.52.4.1317.

Raimbault, P., and N. Garcia (2008), Evidence for efficient regenerated production and dinitrogen fixation in nitrogen-deficient waters of the South Pacific Ocean: Impact on new and export production estimates, Biogeosciences, 5, 323-338, doi:10.5194/bg-5-323-2008. 
Rees, A. P., J. A. Gilbert, and B. A. Kelly-Gerreyn (2009), Nitrogen fixation in the western English Channel (NE Atlantic Ocean), Mar. Ecol. Prog. Ser., 374, 7-12, doi:10.3354/meps07771.

Saito, M. A., and D. L. Schneider (2006), Examination of precipitation chemistry and improvements in precision using the $\mathrm{Mg}(\mathrm{OH})_{2}$ preconcentration inductively coupled plasma mass spectrometry (ICP-MS) method for high-throughput analysis of open-ocean $\mathrm{Fe}$ and $\mathrm{Mn}$ in seawater, Anal. Chim. Acta, 565, 222-233, doi:10.1016/j.aca.2006.02.028.

Sohm, J. A., and D. G. Capone (2010), Zonal differences in phosphorus pools, turnover and deficiency across the tropical North Atlantic Ocean, Global Biogeochem. Cycles, 24, GB2008, doi:10.1029/2008GB003414. Staal, M., S. Lintel Heckert, G. J. A. Brummer, M. Veldhuis, C. Sikkens, S. Persijn, and L. J. Stal (2007), Nitrogen fixation along north-south transect in the eastern Atlantic Ocean, Limnol. Oceanogr., 52, 1305-1316, doi:10.4319/1o.2007.52.4.1305.
Tripp, H. J., S. R. Bench, K. A. Turk, R. A. Foster, B. A. Desany, F. Niazi, J. P. Affourtit, and J. P. Zehr (2010), Metabolic streamlining in an openocean nitrogen-fixing cyanobacterium, Nature, 464, 90-94, doi:10.1038/ nature 08786

J. A. Hilton and J. P. Zehr, Department of Ocean Sciences, University of California Santa Cruz, Santa Cruz, CA 95064, USA.

A. E. Noble and M. A. Saito, Marine Chemistry and Geochemistry Department, Woods Hole Oceanographic Institution, Woods Hole, MA 02543, USA.

J. A. Sohm and E. A. Webb, Department of Biological Sciences, University of Southern California, Los Angeles, CA 90089, USA. (sohm@usc.edu) 